\title{
PERILAKU 3M BAGI PENGHUNI RUMAH MEMPENGARUHI KEJADIAN PENYAKIT DEMAM BERDARAH DENGUE
}

Nur Fauziah*, Umi Rahayu, Imam Thohari

Jurusan Kesehatan Lingkungan, Politeknik Kesehatan Kemenkes Surabaya

*Email korespondensi: fauziahnur30@gmail.com

\begin{abstract}
ABSTRAK
Tindakan pencegahan penyakit Demam Berdarah Dengue dilakukan dengan pengendalian terhadap vektor melalui pemberantasan jentik nyamuk Aedes aegypti yang dapat dikombinasikan dengan perilaku menguras, menutup dan mengubur (3M) sehingga akan menjadi lebih efektif dalam mencegah penyakit DBD. Tujuan dari penelitian ini adalah untuk mengetahui hubungan keberadaan kontainer dengan perilaku 3M (menguras, mengubur, menutup) penghuni terhadap kejadian penyakit DBD.

Jenis penelitian ini adalah penelitian Analitik dengan menggunakan studi Case Contro/dan dilakukan di wilayah kerja Puskesmas Tenggilis dengan besar sampel sebanyak 20 rumah penderita DBD tahun 2016 dan 20 rumah kontrol. Teknik pengambilan sampel menggunakan teknik simple random sampling yang kemudian dianalisis menggunakan uji chi-square dan regresi binary logistic dengan derajat kesalahan (a) sebesar 0,05.

Hasil penelitian menunjukkan bahwa, variabel yang berhubungan dengan kejadian Demam Berdarah Dengue di wilayah kerja Puskesmas Tenggilis adalah Sikap ( $p$ value : $0,013<0,05)$ dan Tindakan $(p$ value $: 0,027<0,05)$ terkait 3M serta Keberadaan Kontainer ( $p$ value $: 0,038<0,05)$. Sedangkan variabel yang tidak berhubungan dengan kejadian Demam Berdarah Dengue adalah Pengetahuan terkait 3M ( $p$ value : $0.376>0,05)$. Variabel yang paling mempengaruhi kejadian Demam Berdarah Dengue adalah Sikap responden terkait 3M.

Hendaknya masyarakat meningkatakan kepedulian terhadap kebersihan lingkungan dan kesadaran akan pentingnya menguras bak mandi secara rutin. Sedangkan bagi instansi Puskesmas dapat lebih sering memberikan edukasi dan informasi terkait penyakit demam berdarah dengue kepada masyarakat.
\end{abstract}

Kata kunci : DBD, Kontainer, 3M

\section{PENDAHULUAN}

Di Indonesia permasalahan kesehatan terkait penyakit menular masih menjadi beban yang belum dapat dituntaskan hingga saat ini (Widoyono, 2014). Salah satu contoh penyakit menular yang masih menjadi permasalahan di Indonesia adalah penyakit Demam Berdarah Dengue.

Demam berdarah dengue merupakan penyakit yang disebabkan oleh virus dengue I, II, III, dan IV, serta ditularkan melalui perantara vektor nyamuk Aedes aegyptidan Aedes albopictus (Soegijanto, 2009). Infeksi virus terjadi melalui gigitan nyamuk kemudian memasuki aliran darah untuk bereplikasi (memperbanyak diri) setelah itu, tubuh akan membentuk antibodi (Widoyono, 2014). Tempat perindukan yang paling disukai oleh nyamuk Aedes adalah tempat yang berwarna gelap, terbuka lebar dan terlindungi dari sinar matahari langsung. Selain itu, nyamuk Aedes juga berkembang biak pada air yang jernih dengan kondisi tidak berkontak langsung dengan tanah seperti air bersih pada bak mandi, tempayan, drum, gentong, vas bunga, pot tanaman hias, ban bekas, kaleng bekas, botol bekas, tempat minum burung serta barang-barang yang dapat menampung air lainnya (Soegijanto, 2004).

Data dari seluruh dunia menunjukkan bahwa Asia menempati urutan pertama dalam jumlah penderita DBD setiap tahun nya. Sementara itu, terhitung sejak 1968 hingga tahun 2009, World Health Organization (WHO) mencatat negara Indonesia sebagai negara dengan kasus DBD tertinggi di Asia Tenggara. 
Menurut data Kementerian Kesehatan tahun 2016 provinsi Jawa Timur merupakan salah satu wilayah di Indonesia yang memiliki jumlah kasus DBD dengan jumlah penderita mencapai 24.005 jiwa dan sebanyak 340 jiwa diantaranya meninggal dunia. Salah satu daerah di Jawa Timur yang masuk dalam wilayah endemis DBD adalah kota Surabaya dengan jumlah penderita pada tahun 2016 menurut data Dinas Kesehatan Kota Surabaya mencapai 938 penderita yang tersebar dalam 31 kecamatan dan memiliki nilai CFR sebesar $0,75 \%$.

Tindakan pencegahan meluasnya penyakit DBD dilakukan dengan pengendalian terhadap vektor melalui pemberantasan jentik nyamuk Aedes aegypti dengan beberapa metode yang tepat yaitu secara fisik, biologis dan kimiawi. Metode ini apabila dikombinasikan dengan perilaku menguras, menutup dan memanfaatkan/mendaur ulang barang bekas (3M) akan menjadi cara yang efektif dalam mencegah penyakit DBD.

Penelitian Respati Y.K., dan Keman, S., tahun 2006 di kelurahan Pacar Keling Surabaya menyimpulkan bahwa terdapat hubungan antara perilaku 3M terhadap kejadian Demam Berdarah Dengue, dimana hasil uji statistik menggunakan chi square mendapatkan nilai $\mathrm{p}$ value sebesar 0,01 dengan hipotesis yaitu terdapat hubungan antara variabel yang diteliti dengan kejadian penyakit DBD jika nilai $\mathrm{p}$ value < dari alfa $(0,05)$.

Pada tahun 2016, salah satu wilayah di Surabaya yang memiliki jumlah penderita DBD tertinggi adalah wilayah Tenggilis dengan jumlah mencapai 65 orang.

Tujuan dari penelitian ini adalah Mengetahui hubungan keberadaan kontainer dengan perilaku 3M (menguras, menutup, memanfaatkan/mendaur ulang) penghuni terhadap kejadian penyakit DBD (Studi Pada Wilayah Kerja Puskesmas Tenggilis Kota Surabaya Tahun 2018).

\section{METODE PENELITIAN}

Jenis penelitian adalah penelitian Analitik dengan menggunakan studi Case Control dan metode survey, yaitu suatu cara penelitian deskriptif yang dilakukan terhadap sekumpulan objek yang biasanya cukup banyak dalam jangka waktu tertentu (Notoatmodjo, 2010).

Populasi pada penelitian ini adalah jumlah rumah penderita Demam Berdarah Dengue (DBD) tahun 2016 di 4 kelurahan wilayah kerja Puskesmas Tenggilis sebanyak 65 rumah. Dari jumlah populasi yang ada maka jumlah sampel yang didapatkan adalah sebanyak 20 rumah.

Variabel Bebas pada penelitian ini adalah keberadaan kontainer dan perilaku penderita. Sedangkan Variabel Terikat pada penelitian ini adalah kejadian Demam Berdarah Dengue (DBD).

Dalam hal ini, data primer yang dikumpulkan oleh peneliti adalah data penilaian perilaku responden meliputi pengetahuan, sikap dan tindakan yang akan di dapatkan dengan memberikan kuisioner kepada responden. Selain itu, data primer lainnya adalah data mengenai keberadaan kontainer yang akan di dapatkan melalui lembar observasi. Sedangkan, data sekunder yang di dapatkan peneliti dari instansi terkait adalah data jumlah penderita atau kasus DBD pada setiap kelurahan tahun 2016, data jumlah RW pada masing-masing kelurahan, data jumlah penduduk, data jumlah KK, data jumlah rumah serta data presentase $A B J$ pada masing-masing kelurahan di tahun 2016.

Uji yang digunakan dalam penelitian ini adalah uji chi-square untuk analisis secara bivariat dan uji Regresi binary logistic

\section{HASIL DAN PEMBAHASAN}

Berdasarkan data sekunder yang didapatkan dari puskesmas Tenggilis, jumlah total kasus demam berdarah dengue pada tahun 2016 adalah sebanyak 65 orang yang tersebar pada 4 kelurahan yaitu Kutisari, Kendangsari, Tenggilis Mejoyo, dan Panjang Jiwo (Tabel 1).

Tabel 1.

DISTRIBUSI JUMLAH KEJADIAN PENYAKIT DEMAM BERDARAH DENGUE No Nama Kelurahan Populasi Sampel 


\begin{tabular}{clll}
\hline 1. & Kutisari & 22 Rumah & 7 Rumah \\
\hline 2. & Kendangsari & 16 Rumah & 5 Rumah \\
\hline 3. & Tenggilis Mejoyo & 16 Rumah & 5 Rumah \\
\hline 4. & Panjang Jiwo & 11 Rumah & 3 Rumah \\
\hline & Jumlah & 65 Rumah & 20 Rumah \\
\hline & Sumber : Data Sekunder Puskesmas Tenggilis
\end{tabular}

Berdasarkan tabel 1 diatas dapat diketahui bahwa distribusi penderita pada masing masing wilayah kerja adalah 22 penderita untuk kelurahan Kutisari, 16 penderita pada kelurahan Kendangsari, 16 penderita pada kelurahan Tenggilis Mejoyo dan di kelurahan Panjang Jiwo sebanyak 11 penderita. Dalam kurun waktu 5 tahun terakhir, penderita DBD yang dilaporkan di puskesmas Tenggilis memiliki grafik yang tidak konstan dengan jumlah penderita yang naik turun.
Menurut data puskesmas Tenggilis, pada tahun 2012 didapatkan 24 laporan kasus demam berdarah dengue, pada tahun 2013 sebanyak 89 kasus, pada tahun 2014 sebanyak 16 kasus, pada tahun 2015 sebayak 59 kasus dan pada tahun 2016 terdapat 65 kasus.

1. Hubungan Antara Keberadaan kontainer dengan Kejadian DBD di Wilayah Kerja Puskesmas Tenggili

Tabel 2.

DISTRIBUSI KEBERADAAN KONTAINER

\begin{tabular}{|c|c|c|c|c|c|c|}
\hline $\begin{array}{c}\text { Jenis } \\
\text { Kontainer }\end{array}$ & Jumlah & $\begin{array}{l}\text { Negatif } \\
\text { Jentik }\end{array}$ & $\begin{array}{l}\text { Positif } \\
\text { Jentik }\end{array}$ & $\% \mathrm{CI}$ & $\begin{array}{l}\text { ¿Rumah } \\
+ \text { Jentik }\end{array}$ & $\begin{array}{l}\% \\
\mathrm{HI}\end{array}$ \\
\hline \multicolumn{7}{|c|}{ Untuk Keperluan Sehari-hari } \\
\hline Bak Mandi & 40 & 31 & 9 & 22,5 & \multirow{12}{*}{12} & \multirow{12}{*}{30} \\
\hline Gentong & 21 & 20 & 1 & 4,76 & & \\
\hline Tandon & 0 & 0 & 0 & 0 & & \\
\hline Ember & 16 & 16 & 0 & 0 & & \\
\hline Lainnya & 0 & 0 & 0 & 0 & & \\
\hline Jumlah & 77 & 67 & 10 & 12,9 & & \\
\hline \multicolumn{5}{|c|}{ Bukan untuk keperluan sehari-hari } & & \\
\hline Dispenser & 15 & 11 & 4 & 26,67 & & \\
\hline Air kulkas & 6 & 6 & 0 & 0 & & \\
\hline $\begin{array}{l}\text { Minum } \\
\text { burung }\end{array}$ & 4 & 4 & 0 & 0 & & \\
\hline $\begin{array}{l}\text { Lainnya } \\
\text { (Baskom) }\end{array}$ & 1 & 1 & 0 & 0 & & \\
\hline Jumlah & 26 & 22 & 4 & 15,3 & & \\
\hline
\end{tabular}

Berdasarkan tabel 2 di atas, dapat diketahui bahwa dari 40 rumah responden yang diteliti didapatkan hasil bahwa 12 rumah positif terhdapat keberadaan jentik dengan presentasi House Index sebesar $30 \%$ dan distribusi jumlah kontainer untuk keperluan sehari-hari sebanyak 77 kontainer dengan 67 kontainer negatif jentik dan 10 kontainer positif jentik. Selain itu, kontainer yang bukan untuk keperluan sehari-hari sebanyak 26 kontainer dengan 22 kontainer negatif jentik dan 4 kontainer positif jentik. Dalam hal ini bak mandi merupakan jenis kontainer yang paling banyak ditemukan jentik. Dari uji statistik menggunakan analisis Chi Square, diperoleh hasil bahwa nilai $p$ value sebesar $0,036<$ a $(0,05)$ sehingga terdapat hubungan yang bermakna secara statistik antara keberadaan kontainer yang positif jentik dengan kejadian DBD di wilayah kerja puskesmas Tenggilis. Selain itu, didapatkan nilai OR (Odd Ratio) sebesar 
4,636 yang artinya rumah responden yang positif jentik memiliki peluang 4,636 kali lebih besar untuk menderita penyakit DBD dibandingkan dengan rumah responden yang negatif jentik. Hasil penelitian ini sejalan dengan penelitian yang dilakukan oleh Widjaja (2011) dan Yudhastuti dan Vidiyani (2005) bahwa hasil penelitian menunjukkan bak mandi adalah jenis kontainer yang paling dominan ditemukan jentik. Menurut Zulkoni (2011), Vektor penyakit Demam Berdarah Dengue (DBD) adalah nyamuk Aedes aegypti dan Aedes albopictus. Telur nyamuk Aedes diletakkan di atas permukaan air dan menempel pada dinding-dinding perindukan. Tempat perindukan yang disenangi nyamuk biasanya seperti bak mandi, pot bunga, kaleng, botol, drum, ban mobil bekas, tempurung, tunggak bambu serta benda lain yang dapat menampung air.

Tabel 3.

HUBUNGAN ANTARA PENGETAHUAN, SIKAP, DAN TINDAKAN RESPONDEN 3M DENGAN KEJADIAN DBD

\begin{tabular}{|c|c|c|c|c|c|c|c|c|c|c|}
\hline \multirow[t]{3}{*}{ No } & \multirow[t]{3}{*}{ Variabel } & \multirow[t]{3}{*}{ Kategori } & \multicolumn{4}{|c|}{ Responden } & \multicolumn{2}{|c|}{ Total } & \multirow{3}{*}{$\begin{array}{c}\text { Chi } \\
\text { Square }\end{array}$} & \multirow[t]{3}{*}{ OR } \\
\hline & & & \multicolumn{2}{|c|}{ Kasus } & \multicolumn{2}{|c|}{ Kontrol } & \multirow[b]{2}{*}{$\mathrm{N}$} & \multirow[b]{2}{*}{$\%$} & & \\
\hline & & & $\mathrm{n}$ & $\%$ & $n$ & $\%$ & & & & \\
\hline \multirow[t]{4}{*}{1.} & Pengetahuan & Baik & 16 & 80 & 18 & 90 & 34 & 85 & \multirow[t]{4}{*}{0,376} & \multirow[t]{4}{*}{2,25} \\
\hline & & Cukup & 4 & 20 & 2 & 10 & 6 & 15 & & \\
\hline & & Kurang & 0 & 0 & 0 & 0 & 0 & 0 & & \\
\hline & \multicolumn{2}{|c|}{ Total } & 20 & 100 & 20 & 100 & 40 & 100 & & \\
\hline \multirow[t]{4}{*}{2} & Sikap & Baik & 11 & 55 & 18 & 90 & 29 & 72,5 & \multirow[t]{4}{*}{0,013} & \multirow[t]{4}{*}{7,364} \\
\hline & & Cukup & 9 & 45 & 2 & 10 & 11 & 27,5 & & \\
\hline & & Kurang & 0 & 0 & 0 & 0 & 0 & 0 & & \\
\hline & \multicolumn{2}{|c|}{ Total } & 20 & 100 & 20 & 100 & 40 & 100 & & \\
\hline \multirow[t]{4}{*}{3} & Tindakan & Baik & 14 & 70 & 7 & 35 & 21 & 52,5 & \multirow[t]{4}{*}{0,027} & \multirow[t]{4}{*}{0,231} \\
\hline & & Cukup & 6 & 30 & 13 & 65 & 19 & 47,5 & & \\
\hline & & Kurang & 0 & 0 & 0 & 0 & 0 & 0 & & \\
\hline & Total & & 20 & 100 & 20 & 100 & 40 & 100 & & \\
\hline
\end{tabular}

Berdasarkan tabel 3 diatas, menunjukkan bahwa dari 40 responden terdapat responden $16(80 \%)$ yang memiliki pengetahuan terkait kegiatan $3 \mathrm{M}$ dengan kategori baik dan 4 responden memiliki pengetahuan dengan kategori cukup (20\%). Sedangkan pada kelompok kontrol terdapat 18 responden (90\%) yang memiliki pengetahuan terkait $3 \mathrm{M}$ dengan kategori baik dan 2 responden memiliki pengetahuan dengan kategori baik (10 \%).

Dari uji statistik menggunakan analisis Chi Square, diperoleh hasil $p$ value sebesar $0,376>$ a $(0,05)$ sehingga tidak terdapat hubungan yang bermakna secara statistik antara pengetahuan responden terkait kegiatan $3 \mathrm{M}$ dengan kejadian DBD diwilayah kerja Puskesmas Tenggilis. Selain itu, didapatkan nilai OR (Odd Ratio) sebesar 2,25 yang artinya responden dengan pengetahuan yang cukup terhadap kegiatan 3M akan memiliki peluang 2,25 kali lebih besar untuk menderita penyakit DBD dibandingkan dengan responden yang memiliki pengetahuan terkait $3 \mathrm{M}$ dalam kategori baik. Namun, hal tersebut tidak lepas dari berbagai faktor internal maupun faktor eksternal yang mempengaruhi tingkat pengetahuan seseorang. Sehingga dengan demikian, tingkatan pengetahuan akan menjadi salah satu faktor penyebab terjadinya penyakit jika di ikuti dengan berbagai faktor lain yang mendukung seperti sikap dan tindakan yang dilakukan.

Menurut Sukmadinata (2003), Tingginya presentase responden yang berpengetahuan baik dapat dipengaruhi oleh berbagai faktor seperti pendidikan, paparan media massa, setatus ekonomi, hubungan sosial, dan pengalaman. Dimana berdasarkan hal tersebut, 
pengalaman seseorang terhadap penyakit demam berdarah dan adanya paparan media massa seperti edukasi tentang penyakit demam berdarah di televisi dapat menjadi faktor yang turut mempengaruhi tingginya pengetahuan responden yang diteliti.

2. Hubungan Antara Sikap Responden Terkait 3M dengan Kejadian 3M.

Berdasarkan tabel 3 diatas, menunjukkan bahwa dari 40 dapat diketahui bahwa pada kelompok kasus terdapat 11 responden memiliki sikap dengan kategori baik (55\%) dan 9 responden ( $45 \%$ ) yang memiliki sikap dengan kategori cukup. Sedangkan pada kelompok kontrol terdapat 18 responden memiliki sikap dengan kategori baik (90 $\%$ ) dan 2 responden (10\%) yang memiliki sikap dengan kategori cukup.

Dari uji statistik, diperoleh hasil bahwa $p$ value sebesar $0,013<a(0,05)$ sehingga terdapat hubungan yang bermakna secara statistik antara sikap responden terkait kegiatan $3 \mathrm{M}$ dengan kejadian DBD diwilayah kerja Puskesmas Tenggilis. Menurut Notoatmojo (2012) Sikap merupakan reaksi atau respon yang masih tertutup dari seseorang terhadap suatu stimulus atau objek. Manisfestasi dari sikap tidak dapat langsung di lihat sehingga suatu sikap belum otomatis terwujud dalam suatu tindakan. Namun, sikap dapat menjadi salah satu faktor yang mendukung kecenderungan seseorang untuk bertindak. Sehingga berdasarkan teori tersebut, baiknya sikap seseorang dalam menanggapi kegiatan 3M dapat mendukung terwujudnya tindakan yang baik pula.

Selain itu, didapatkan nilai OR (Odd Ratio) sebesar 7,364 yang artinya responden dengan sikap yang cukup terhadap kegiatan 3M akan memiliki peluang 7,364 kali lebih besar untuk menderita penyakit DBD dibandingkan dengan responden yang memiliki sikap terkait 3M dalam kategori baik. Hal ini sejalan dengan penelitian yang dilakukan oleh Fathi dkk (2005), dimana dalam jurnalnya menerangkan bahwa semakin masyarakat bersikap tidak serius dan tidak berhati-hati terhadap penularan penyakit DBD maka akan semakin beresiko terjadi penularan penyakit DBD.

3. Hubungan Antara Tindakan Responden Terkait 3M dengan Kejadian DBD

Berdasarkan tabel 3 diatas, menunjukkan bahwa dari 40 responden dapat diketahui bahwa pada kelompok kasus terdapat 14 responden memiliki tindakan terkait $3 \mathrm{M}$ dengan kategori baik (70 \%) dan 6 responden (30\%) yang memiliki tindakan dengan kategori cukup. Sedangkan pada kelompok kontrol terdapat 7 responden memiliki tindakan terkait 3M dengan kategori baik (35\%) dan 13 responden $(65 \%)$ yang memiliki tindakan dengan kategori cukup.

Dari uji statistik dengan metode analisis Chi Square, diperoleh hasil bahwa $p$ value sebesar $0,027<a(0,05)$ sehingga terdapat hubungan yang bermakna secara statistik antara tindakan responden terkait kegiatan 3M dengan kejadian DBD diwilayah kerja Puskesmas Tenggilis. Hal ini sejalan dengan penelitian dilakukan Suyasa dkk (2008) yang menunjukkan bahwa ada hubungan antara tindakan responden dengan keberadaan vektor DBD. Hal tersebut diperkuat dengan teori yang dikeluarkan oleh Depkes RI tahun 2010 bahwa terdapat beberapa Perilaku yang mempengaruhi kejadian penyakit Demam Berdarah Dengue (DBD) yaitu frekuensi pengurasan bak penampungan air, kebiasaan menimbun barang bekas yang berpotensi sebagai tempat penampungan air, dan kebiasaan mengantung pakaian kotor

Selain itu, didapatkan nilai OR (Odd Ratio) sebesar 0,231 yang artinya responden dengan tindakan yang cukup terhadap kegiatan 3M akan memiliki peluang 0,231 kali lebih besar untuk menderita penyakit DBD dibandingkan dengan responden yang memiliki pengetahuan terkait 3M dalam kategori baik.

4. Hubungan Antara Keberadaan Kontainer Dan Prilaku Penghuni Terkait 3M Terhadap Kejadian Penyakit Dbd Di Wilayah Kerja Puskesmas Tenggilis 
Tabel 4.

HASIL ANALISIS MULTIVARIAT ANTARA KEBERADAAN KONTAINER DAN PERILAKU PENGHUNI TERKAIT 3M

\begin{tabular}{llllllll}
\hline No & Variabel & B & Pwald & OR & \multicolumn{2}{c}{$95 \%$ CI } & \multirow{2}{*}{ Pvalue } \\
\cline { 1 - 3 } & & & & Lower & Upper & \\
\hline 1 & $\begin{array}{l}\text { Sikap } \\
\text { Responden } \\
\text { terkait } \\
\text { Kegiatan 3M }\end{array}$ & 3,129 & 6,109 & 22,86 & 1,911 & 273,411 & 0,013 \\
& & & & & & \\
\hline 2 & $\begin{array}{l}\text { Tindakan } \\
\text { Responden } \\
\text { terkait } \\
\text { Kegiatan 3M }\end{array}$ & $-1,743$ & 4,292 & 0,175 & 0,034 & 0,910 & 0,038 \\
\hline 3 & $\begin{array}{l}\text { Keberadaan } \\
\text { Kontainer } \\
\text { Penampung Air } \\
\text { Bersih }\end{array}$ & 2,468 & 4,339 & 11,803 & 1,157 & 120,411 & 0,037 \\
\hline
\end{tabular}

Berdasarkan analisis multivarait menggunakan metode Regresi Binary Logistic didapatkan hasil bahwa dari 4 variabel yang memenuhi syarat untuk menjadi kandidat uji, hanya terdapat 3 variabel yang memiliki nilai $p$ value lebih kecil dari alfa $(p$ value $<a)$ yaitu variabel sikap,tindakan dan keberadaan kontainer penampung air bersih. Sedangkan untuk variabel yang memiliki hubungan paling signifikan adalah variabel sikap dengan nilai odd ratio (OR) paling besar yaitu 22,86 sehingga dapat dikatakan bahwa variabel sikap merupakan variabel yang paling mempengaruhi kejadian penyakit DBD di wilayah kerja puskesmas Tenggilis. Hal tersebut sejalan dengan penelitian yang dilakukan oleh Monintja (2015) yang menerangkan bahwa sikap merupakan variabel yang paling dominan berhubungan dengan tindakan PSN DBD masyarakat Kelurahan Malalayang I dengan nilai OR sebesar 19,358 yang berarti orang dengan sikap baik memiliki peluang 19,358 kali untuk melakukan tindakan PSN dibandingkan ornag yang memiliki sikap kurang baik.

\section{KESIMPULAN}

Terdapat hubungan yang bermakna secara statistik antara sikap dan tindakan terkait 3M dengan kejadian DBD di wilayah kerja puskesmas Tenggilis.

\section{SARAN}

Bagi Puskesmas Tenggilis dapat Lebih sering memberikan edukasi dan informasi terkait penyakit demam berdarah dengue serta dapat lebih meningkatkan komunikasi antar kader dalam setiap wilayah sehingga informasi mengenai adanya penderita DBD di masing-masing wilayah dapat lebih cepat di dapatkan.

\section{DAFTAR PUSTAKA}

Fathi dkk, 2005. Peran Faktor Lingkungan Dan Perilaku Terhadap Penularan Demam Berdarah Dengue Di Kota Mataram. FKM Universitas Airlangga. Vol 2, No 1. 1-10. http://www.journal.unair.ac.id/filer PDF/KESLING-2-1-01.pdf

Monintja, Tyrsa C.N, 2015. Hubungan Antara Karakteristik Individu, Pengetahuan dan Sikap Dengan Tindakan PSN DBD Masyarakat Kelurahan Malalayang I Kecamatan Malalayang Kota Manado. Fakultas Kedokteran Universitas Sam Ratulangi Manado. JIKMU, Vol 5, No 2b April 2015.

Notoatmojo, S, 2010. Metodologi Penelitian Kesehatan. Jakarta, PT Rineka Cipta

Notoatmojo, S, 2012. Promosi Kesehatan Dan Perilaku Kesehatan. Jakarta, PT Rineka Cipta

Respati, Yunita Ken dan Keman, Soedjajadi, 2007. Perilaku 3m, Abatisasi Dan Keberadaan Jentik 


Aedes Hubungannya
Kejadian Dengan
Dengue. Fakultas $\begin{gathered}\text { Berdarah } \\ \text { Kesehatan } \\ \text { Masyarakat Universitas Airlangga } \\ \text { Surabaya Vol.3 (2). 107-118. } \\ \text { https://media.neliti.com/media/pu } \\ \text { blications/3926-ID-perilaku-3m- } \\ \text { abatisasi-dan-keberadaan-jentik- } \\ \text { aedes-hubungannya-dengan- } \\ \text { kejadian-de.pdf }\end{gathered}$

Soegijanto, S. 2009. Kumpulan Makalah Penyakit Tropis Dan Tropis Di Indonesia. Surabaya: Airlangga Univercity Press.

Sukmadinata, N. S, 2003. Landasan Psikologi Proses Pendidikan. Bandung, PT Remaja Rosdakarya.

Suyasa, I N Gede dkk, 2007. Hubungan Faktor Lingkungan dan Perilaku Masyarakat dengan Keberadaan Vektor Demam Berdarah Dengue (DBD) di Wilayah Kerja Puskesmas
I Denpasar Selatan. Politeknik Kesehatan Denpasar Jurusan Kesehatan Lingkungan. Vol.3 (1) : 1

https://ojs.unud.ac.id/index.php/E COTROPHIC/article/view/2484/171 2

Widjaja, Junus, 2011. Keberadaan Kontainer sebagai Faktor Risiko Penularan Demam Berdarah Dengue di Kota Palu, Sulawesi Tengah. Sulawesi Tengah, Vol 3 No 2. https://media.neliti.com/media/pu blications/53866-ID-keberadaankontainer-sebagai-faktor-risi.pdf Widoyono, 2014. Penyakit Tropis. Semarang, Penerbit Erlangga.

Zulkoni, A, 2011. Parasitologi Untuk Keperawatan, Kesehatan Mayarakat, Teknik Lingkungan. Yogyakarta, Nuha Medika. 